\title{
ARAŞTIRMA / RESEARCH \\ Comparison of the efficacy of trauma scores in predicting prognosis and hospitalization
}

Travma skorlarının prognozu ve hastaneye yatışı öngörmede etkinliğinin karşılaştırılması

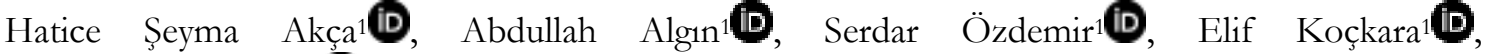
Serkan Emre Eroğlu1

${ }^{1}$ University of Health Sciences, Ümraniye Education and Research Hospital, Department of Emergency Medicine, Istanbul, Turkey.

Cukurova Medical Journo
Abstract
Purpose: The aim of this study was to compare the
efficacy of ISS (injury Severity Score), RTS (Revised
Trauma Score) and ViEWS (VitalPAC Early Warning
Score) scoring systems in predicting prognosis and
mortality.
Materials and Methods: Patients over the age of 18 who
presented with multitrauma were prospectively examined
between May 1, 2019 and November 1, 2019. Trauma
scores, clinical outcomes within the first 24 hours, surgery
requirement and 30 -day mortality data were recorded.
Results: The study included 435 patients, of whom 333
(76.6\%) were male. The median age was 34 (IQR: $18-90$ )
years. It was observed that ISS, RTS and ViEWS had a
significant relationship with 30 -day mortality. In the ROC
analysis of 30 -day mortality, no statistically significant
difference was observed between the ISS, RTS, and
ViEWS AUC values. There was also no statistically
significant difference in terms of the ISS, RTS and ViEWS
according to the length of hospital stay and surgery
requirement.
Conclusion: In addition to their relationship with
mortality, it should be kept in mind that the investigated
scoring systems may also be related to the length of
hospital stay and surgery requirement.
Keywords:. ISS, RTS, ViEWS, trauma scores, trauma, mortality
2021;46(4):1596-1605

Öz

Amaç: Bu çalışmada travma skorlama sistemlerinden ISS (Injury Severity Score), RTS (Revised Trauma Score) ve VIEWS (VitalPAC Early Warning Score)'in prognoza ve mortaliteye etkilerinin karşılaştırılması amaçlanmıștır.

Gereç ve Yöntem: Multitravma ile gelen 18 yaş üstü onam alınan hastalar 01.05.2019-01.11.2019 tarihleri arasinda prospektif olarak incelendi. Travma skorlar1, ilk 24 saatlik klinik sonlanım, cerrahi gerekliliği ve 30 günlük mortalite verileri kaydedildi.

Bulgular: Çalışmaya 435 hasta dahil edildi. Hastaların 333 'ü (\%76,6) erkek idi. Yaş median değeri 34(IQR:18-90) idi. 30 günlük mortalite oranı, ilk 24 saatte hospitalizasyon oranı, ICU yatış oranı ve cerrahi gereklilik oranı sırasıyla; $\% 1,1, \% 19,1, \% 1,8$ ve $\% 8,5$ idi. ISS, RTS ve VİEWS'in 30 günlük mortalite ile anlamlı ilişkisi olduğu gözlendi. 30 günlük mortalite ile ilgili olarak yapılan ROC analizinde ISS, RTS, and VIEWS AUC değerleri arasında istatistiksel olarak anlamlı fark bulunmamıştır. Hastanede yatış süresi ve operasyon gerekliliği açısından da ISS, RTS ve VIEEWS arasında istatistiksel olarak anlamlı fark bulunmamıştır.

Sonuç: Travma skorlama sistemlerinin mortalite ile ilişkisinin karşılaştırılmasının yanıııra, hastanede kalış süresi ve operasyon ihtiyacı olup olmaması ile bu skorlama sistemlerinin ilişkili olabileceği unutulmamalıdır.

Anahtar kelimeler: ISS, RTS, VİEWS, travma skorlar1, travma, mortalite

Yazışma Adresi/Address for Correspondence: Dr. Hatice Şeyma Akça, Address: University of Health Sciences, Umraniye Education and Research Hospital, Department of Emergency Medicine, Istanbul, Turkey

E-mail: drhaticeseyma_@hotmail.com

Geliş tarihi/Received: 15.08.2021 Kabul tarihi/Accepted: 23.10.2021 Cevrimiçi yayın/Published online: 22.11.2021 


\section{INTRODUCTION}

Trauma is one of the leading causes of death in young people. Among the exogenous factors that lead to trauma-related mortality are damage incurred within the first hour and causes secondary to resuscitation and surgery (hypoxia, metabolic acidosis, hypothermia, intracranial hypertension, thoracic injuries, acute respiratory distress syndrome, fat embolism, and tissue ischemia due to organ perfusion failure $)^{1-3}$. In wars, the most common cause of death after trauma is hemorrhagic shock ${ }^{4}$. As a result of the experience gained, the concept of the 'golden hour' emerged. Subsequently, the concept of 'triage' was proposed to provide standardization for the golden hour based on physiological and hemodynamic parameters, and scoring systems were established through the analysis of serious injury and death risk ${ }^{5,6}$.

The first scoring system defined in the literature for this purpose is the Abbreviated Injury Scale (AIS) ${ }^{7}$, which has been revised according to anatomical locations and renamed the Injury Severity Score (ISS). Head, neck, face, chest, abdomen, extremity, and external injuries are scored from 1 to 6 as minor, moderate, serious, severe, critical, and unsurvivable, and the AIS is obtained. The sum of the square of each value taken from minor to unsurvivable gives the ISS (except for identical values) ${ }^{7}$. The Revised Trauma Score (RTS), which was later accepted as a physiological scoring system, includes the Glasgow Coma Scale (GCS), systolic blood pressure, and respiratory rate. Each variable is scored between 0 and $4^{8}$. In addition, peripheral oxygen saturation and oxygen demand have also been used in mortality prediction as an alternative to scoring systems ${ }^{9,10}$. The VitalPAC Early Warning Score (ViEWS) system includes systolic blood pressure and respiratory rate, as well as heart rate, temperature, AVPU (alert, reacting to voice, reacting to pain, unresponsive) score $^{11,12}$. The superiority of the scoring systems over each other allows the comparison of physiological and anatomical examinations. However, considering the variability of trauma patients, it is very important for the physician to evaluate the patient's prognosis at the first examination. For this, an accepted common evaluation score must be used. We speculated that these scoring systems might be superior to each other in predicting prognosis.

The primary aim of our study is to determine whether the ISS, RTS, and ViEWS are effective in determining prognosis. The secondary aim is to investigate whether these anatomical and physiological scoring systems have superiority over each other in determining prognosis.

\section{MATERIALS AND METHODS}

\section{Study design}

The prospective cohort study was conducted in the emergency department of Istanbul Umraniye Training and Research Hospital, which is a tertiary trauma center providing care for an average of 500,000 patients per year. Our hospital emergency room consists of green, yellow, and red areas. Applications made due to trauma are evaluated in the yellow and red areas. The patients' vital signs and examination findings are recorded with 'Health Information Systems v 5.5', and patient follow-up is conducted with the examination request.

For the study, ethical approval was obtained from the local clinical research ethics committee of our hospital (Comparison of the effects of ISS, RTS, and ViEWS on mortality and hospitalization in multitrauma patients admitted to the emergency department, date: May 22, 2019, number: B.10.1.TKH.4.34.H.GP.0.01/111). Patients who had a sufficient level of consciousness and the relatives of patients who were not adequately conscious were invited to participate in the study. An informed consent form was signed by the patients or their relatives who agreed to participate in the study.

\section{Study population}

Patients over the age of 18 who presented with multitrauma between May 1 and November 1, 2019 were examined. Inclusion criteria in our study were patients with multiple traumas over the age of 18 , high-energy traumas even if a single anatomical region was affected, and low-energy multiple traumas affecting more than one anatomical region. The exclusion criteria were all patients under 18 years of age and low-energy traumas affecting a single anatomical region. Further, patients who were initially included in the study but were later determined to have an underlying pathology causing the trauma (stroke, myocardial infarction, etc.) were excluded from the sample.

\section{Patient monitoring}

In our prospective study, trauma patients were evaluated by emergency medicine specialists. ISS, 
RTS, and ViEWS calculations were made by emergency medicine specialists at the first examination. Follow-up of the patients (service admission, discharge, mortality) was done with the help of 'Health Information Systems v 5.5' and 'Hospital Mortality System'.

\section{Data collection}

Demographic data, comorbidities, trauma mechanism, trauma scores, lactate levels, first 24hour clinical outcomes, length of hospital stay, surgery requirement, hospitalized clinics, areas of injury, and 30-day mortality data were recorded. Comorbidities were grouped as hypertension, diabetes, coronary artery disease, and chronic renal failure. Mechanisms of trauma were classified as assault, non-vehicle traffic accident, in-vehicle traffic accident, motorcycle accident, bicycle accident, falls from a height of $\leq 3 \mathrm{~m}$, falls from a height of $>3 \mathrm{~m}$, and gunshot wounds.

Areas of injury were evaluated as head, neck, face, thorax, abdomen, extremities, and external. The ISS, RTS, and ViEWS values were calculated. In the first 24 hours, the patients who were hospitalized and those who recovered were evaluated as having a good prognosis, while those who required intensive care or died were considered to have a poor prognosis. The hospital clinics to which the patients were admittednamely orthopedics, general surgery, thoracic surgery, otolaryngology, ophthalmology, plastic and reconstructive surgery, cardiovascular surgery, neurosurgery, gynecology and obstetrics, and urology-were recorded. The first 24-hour clinical outcomes were grouped as discharge from hospital, hospitalization, admission to intensive care unit (ICU), patient refusal to continue treatment, referral to external hospital, and mortality. The primary outcome of the study was 30-day mortality due to all causes. Our secondary outcomes were first 24-hour clinical outcomes, length of hospital stay, and surgery requirement.

\section{Measures}

\section{Injury Severity Score (ISS)}

Head, neck, face, chest, abdomen, extremity, and external injuries are scored from 1 to 6 as minor, moderate, serious, severe, critical, and unsurvivable, and the AIS is obtained. The sum of the square of each value taken from minor to unsurvivable gives the ISS (except for identical values) (e.g., head neck; moderate (2), abdomen; severe (4), other system examinations are normal: AIS: 6, ISS: 20).

\section{The Revised Trauma Score (RTS)}

If the GCS is 3, systolic blood pressure $0 \mathrm{mmhg}$, respiratory rate $0 / \mathrm{min}$, the RTS value is 0 for each parameter. If the GCS is $4-5$, systolic blood pressure $1-49 \mathrm{mmhg}$, respiratory rate $1-5 / \mathrm{min}$, the RTS value is 1 for each parameter. If the GCS is 6-8, systolic blood pressure $50-75 \mathrm{mmhg}$, respiratory rate 6$9 / \mathrm{min}$, the RTS value is 2 for each parameter. If the GCS is 9-12, systolic blood pressure 76-89 mmh, respiratory rate $>29 / \mathrm{min}$, the RTS value is 3 for each parameter. If the GCS is 13-15, systolic blood pressure $>89 \mathrm{mmHg}$, respiratory rate $10-29 \mathrm{~min}$, the RTS value is 4 for each parameter.

\section{ViEWS}

If the systolic blood pressure is $<70 \mathrm{mmhg}$, heart rate $>130 / \mathrm{min}$, respiratory rate $>30 / \mathrm{min}$ and AVPU score is unresponsive, the ViEWS value is 3 for each parameter. If the systolic blood pressure is $71-80$ mmhg or $>200 \mathrm{mmhg}$, heart rate $<40 / \mathrm{min}$ or 111 $129 / \mathrm{min}$, respiratory rate $<9 / \mathrm{min}$ or $21-29 / \mathrm{min}$, temperature $<35^{\circ} \mathrm{C}$ or $>38.5^{\circ} \mathrm{C}$ and the AVPU score is reacting to pain, the ViEWS value is 2 for each parameter. If the systolic blood pressure is 81 $100 \mathrm{mmhg}$, heart rate $41-50 / \mathrm{min}$ or $101-110 / \mathrm{min}$, respiratory rate $15-20 / \mathrm{min}$, and the AVPU score is reacting to voice, the ViEWS value is 1 for each parameter. If the systolic blood pressure is 101$199 \mathrm{mmhg}$, heart rate $51-100 / \mathrm{min}$, respiratory rate 9$14 / \mathrm{min}$, temperature $35-38.4^{\circ} \mathrm{C}$ and the AVPU score is alert, the ViEWS value is 0 for each parameter.

\section{Statistical analysis}

All statistical analyses were performed using SPSS v. 23.0 for Windows (SPSS Inc., Chicago, IL, USA). Categorical data were expressed as numbers and percentages, and median, minimum, and maximum values were used for non-parametric numerical data without normal spatial distribution. The distribution of numerical data was evaluated using the ShapiroWilk test. The chi-square test was conducted to evaluate the relationship between categorical data. The Mann-Whitney U test was used to compare nonparametric numerical data between the two groups. If there were more than two groups, the Kruskal-Wallis test was used to compare non-parametric numerical data. According to the mortality status, Spearman's correlation analysis was undertaken to determine the relationship between the trauma scoring systems and 
the length of hospital stay. We also formed a receiveroperating characteristic curve (ROC) for 30-day mortality and obtained the area under the curve (AUC) for individual variables. The AUC values of the three scores were calculated and tested between ISS, RTS, and ViEWS or significance using the DeLong equality test. A $p$ value of less than 0.05 was

Table 1. Demographic data, trauma scores, prognostic

\begin{tabular}{|c|c|c|c|c|}
\hline & Total & Survivor & Mortality & p value \\
\hline Age & $34(18-90)$ & $34(18-90)$ & $53(24-80)$ & 0.173 \\
\hline Gender $(n, \%)$ & & & & 0.595 \\
\hline Female & $102(23.4 \%)$ & $102(23.7 \%)$ & $0(0 \%)$ & \\
\hline Male & $333(76.6 \%)$ & $328(76.3 \%)$ & $5(100 \%)$ & \\
\hline \multicolumn{5}{|l|}{ Comorbidities $(\mathrm{n}(+/-), \%)$} \\
\hline Hypertension & $3(0.7 \%)$ & $3 / 427(0.7 \%)$ & $0 / 5$ & \\
\hline Diabetes mellitus & $5(1.1 \%)$ & $5 / 425(1.2 \%)$ & $0 / 5$ & \\
\hline Coronary artery disease & $2(0.5 \%)$ & $1 / 429(0.2 \%)$ & $1 / 4$ & \\
\hline Chronic renal failure & $1(0.2 \%)$ & $1 / 429(0.2 \%)$ & $0 / 5$ & 0.023 \\
\hline Mechanism of trauma & & & & 0.544 \\
\hline Assault & $148(34 \%)$ & $148(34.4 \%)$ & $0(0 \%)$ & \\
\hline Non-vehicle traffic accident & $52(12 \%)$ & $51(11.9 \%)$ & $1(20 \%)$ & \\
\hline In-vehicle traffic accident & $97(22.3 \%)$ & $96(22.3 \%)$ & $1(20 \%)$ & \\
\hline Motorcycle accident & $74(17 \%)$ & $72(16.7 \%)$ & $2(40 \%)$ & \\
\hline Bicycle accident & $3(0.7 \%)$ & $3(0.7)$ & $0(0 \%)$ & \\
\hline Fall from a height of $<3 \mathrm{~m}$ & $34(7.8 \%)$ & $34(7.9 \%)$ & $0(0 \%)$ & \\
\hline Fall from a height of $>3 \mathrm{~m}$ & $24(5.5 \%)$ & $23(5.3 \%)$ & $1(20 \%)$ & \\
\hline Gunshot wound & $3(0.7 \%)$ & $3(0.7 \%)$ & $0(0 \%)$ & \\
\hline \multicolumn{5}{|l|}{ Trauma Scoring } \\
\hline ISS & $6(1-66)$ & $6(1-66)$ & $6(3-66)$ & 0.007 \\
\hline RTS & $7.84(4.6-7.84)$ & $7.84(6.08-7.84)$ & $4.65(1.6-7.84)$ & $<0.001$ \\
\hline ViEWS & $1(1-20)$ & $1(1-10)$ & $13(7-20)$ & $<0.001$ \\
\hline Lactate level $(\mathrm{mmol} / \mathrm{L})$ & $1.5(0.4-19)$ & $1.4(0.4-8.7)$ & $8.4(2.3-19)$ & 0.001 \\
\hline Clinical outcome within the first 24 hours & & & & $<0.001$ \\
\hline Discharge from hospital & $331(76.1 \%)$ & $331(77 \%)$ & $0(0 \%)$ & \\
\hline Admission to inpatient clinics & $83(19.1 \%)$ & $82(19.1 \%)$ & $1(20 \%)$ & \\
\hline Admission to the intensive care unit & $8(1.8 \%)$ & $7(1.6 \%)$ & $1(20 \%)$ & \\
\hline Patient refusal to continue treatment & $9(2.1 \%)$ & $9(2.1 \%)$ & $0(0 \%)$ & \\
\hline Referral to an external hospital & $1(0.2)$ & $1\left(0.2^{\%} \%\right)$ & $0(0 \%)$ & \\
\hline Death & $3(0.7 \%)$ & & $3(60 \%)$ & \\
\hline Length of hospital stay (days) & $1(0-30)$ & $1(1-30)$ & $0(0-14)$ & 0.202 \\
\hline \multicolumn{5}{|l|}{ Operation status } \\
\hline Operated & $37(8.5 \%)$ & $37(8.6 \%)$ & $0(0 \%)$ & \\
\hline Non-operated & $398(91.5 \%)$ & $393(91.4 \%)$ & $5(100 \%)$ & \\
\hline \multicolumn{5}{|l|}{ Inpatient clinics of admitted patients } \\
\hline Orthopedics & $44(10.1 \%)$ & $44\left(10.2^{\%} \%\right)$ & $(0 \%)$ & \\
\hline General surgery & $23(5.3 \%)$ & $22(5.1 \%)$ & $1(20 \%)$ & \\
\hline Thoracic surgery & $4(0.9 \%)$ & $3(0.7 \%)$ & $1(20 \%)$ & \\
\hline Otolaryngology & $1(0.2 \%)$ & $1(0.2 \%)$ & $(0 \%)$ & \\
\hline Ophthalmology & $1(0.2 \%)$ & $1(0.2 \%)$ & $(0 \%)$ & \\
\hline Plastic and reconstructive surgery & $2(0.5 \%)$ & $2(0.5 \%)$ & $(0 \%)$ & \\
\hline Cardiovascular surgery & $1\left(0.2^{0} \%\right)$ & $1\left(0.2^{\circ} \%\right)$ & $(0 \%)$ & \\
\hline Neurosurgery & $11(2.5 \%)$ & $11(2.6 \%)$ & $(0 \%)$ & \\
\hline Gynecology and obstetrics & $1(0.2 \%)$ & $1(0.2 \%)$ & $(0 \%)$ & \\
\hline Urology & $2(0.5 \%)$ & $2(0.5 \%)$ & $(0 \%)$ & \\
\hline Mortality & $5(1.1 \%)$ & & & \\
\hline
\end{tabular}

considered statistically significant for all analyses. The G-power analysis method was used. When the Type 1 error was 0.05 , the total sample size was determined to be 428 in the analysis of two independent groups . Our sample size was created by taking this criterion into accountResults 
During the study period, 630 cases over the age of 18 presented to the emergency department due to trauma. Of these cases, 152 were excluded due to only having minor trauma and 43 refused to participate in the study. As a result, 435 patients were included in the final analysis. The flowchart of the study is presented in Figure 2.

Of the 435 patients, $333(76.6 \%)$ were male. The median age was 34 (IQR: $18-90)$ years. Five (1.14\%) patients who were included in the study died within 30 days after trauma. Furthermore, within the first 24 hours, three patients $(60 \%)$ died-one patient $(20 \%)$ after hospitalization and one patient (20\%) after admission to the ICU. The rates of 30-day mortality, first 24-hour hospitalization, ICU admission, and surgery requirement were $1.1 \%, 19.1 \%, 1.8 \%$, and $8.5 \%$, respectively. The demographic characteristics of the patients, clinical outcomes, clinics to which they were admitted, ISS, RTS, and ViEW scores, and their relationship with mortality are shown in Table 1.

Table 2 presents the ROC analysis results of the relationship of ISS, RTS, and ViEWS with 30-day mortality after admission to the emergency department together with the cut-off, sensitivity, specificity, positive predictive, negative predictive, accuracy, and AUC values. There was no statistically significant difference between the AUC values of ISS, RTS, and ViEWS according to the DeLong equality test (ISS vs RTS, $p=0.547$; ISS vs ViEWS, $p=0.228$; and RTS vs ViEWS, $p=0.104)$. The receiver operating characteristics curve of ISS, RTS, and ViEWS in predicting 30-day mortality is shown in Figure 3.

During the study period, 630 emergency room admissions were made due to

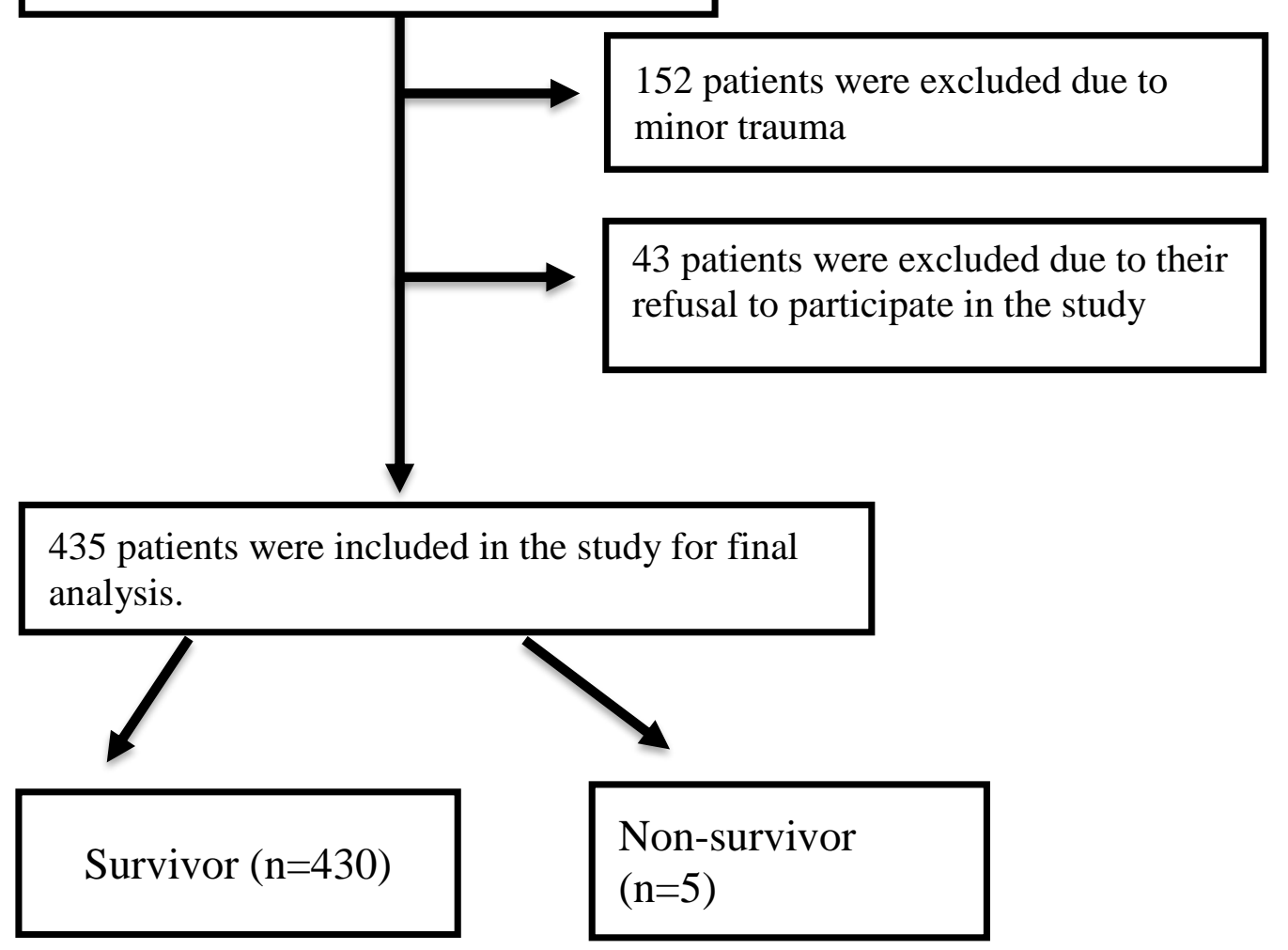

Figure 2. Flow chart of the inclusion and exclusion criteria for the enrolment of patients in the study. 
Table 2. Receiver operating characteristic analysis of ISS, RTS and ViEWS in predicting 30-day mortality

\begin{tabular}{|l|c|c|c|c|c|c|c|}
\hline & Cut-off & Sensitivity & Specificity & PPV & NPV & Accuracy & AUC \\
\hline ISS & $>18$ & 80.00 & 86.98 & 6.7 & 99.7 & 66.98 & 84.7 \\
\hline RTS & $\leq 4.653$ & 60.00 & 100.00 & 100.0 & 99.5 & 60.00 & 79.5 \\
\hline VIEWS & $>6$ & 100.00 & 98.37 & 41.7 & 100.0 & 98.37 & 99.6 \\
\hline
\end{tabular}

ISS, Injury Severity Score; RTS, Revised Trauma Score; ViEWS, VitalPAC Early Warning Score; PPV, positive predictive value; NPV, negative predictive value, AUC, area under the curve

There were $195(44.82 \%)$ patients with head and neck injuries, $143(32.87 \%)$ with facial trauma, 118 $(27.12 \%)$ with thoracic trauma, $69(15.86 \%)$ with abdominal trauma, $324(74.48 \%)$ with extremity trauma, and $163(37.47 \%)$ with external injuries. Head and neck trauma was present in $37(44.57 \%)$ of the 83 patients admitted to inpatient clinics and six (75\%) of the eight patients admitted to the ICU; thoracic trauma in $27(32.53 \%)$ and three $(37.5 \%)$ patients; abdominal trauma in $19(22.89 \%)$ patients and one $(12.5 \%)$ patient; and extremity trauma in 68 $(81.92 \%)$ and four $(50 \%)$ patients, respectively.

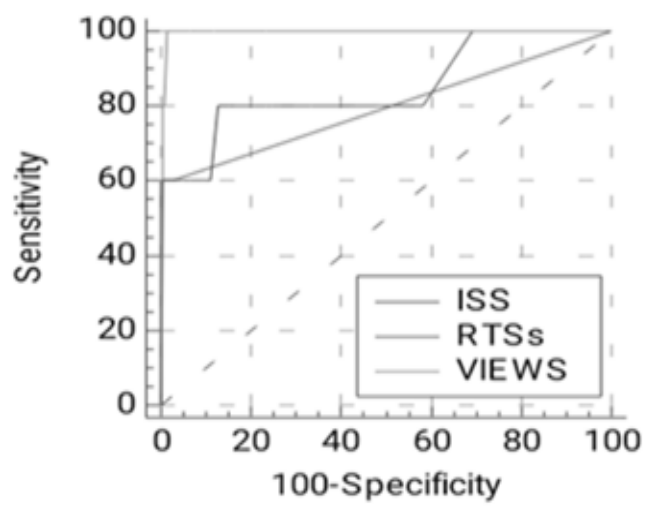

Figure3.Receiver operating characteristics curve of ISS, RTS and ViEWS in predicting 30-day mortality
In patients with a poor prognosis, the median ISS was 41 (1-66), the median RTS was 6.392 (1.605-7.841), and the median ViEWS was 9 (3-20). A statistically significant difference was found in all three scoring systems in terms of discharge and patient prognosis $(p<0.001)$ [Table 3].

When ISS, RTS, and ViEWS were compared according to the length of hospital stay (being $>3$ and $3 \leq$ longer or shorter days), no statistically significant difference was found $(p=0.104, p=0.117$, and $p=0.136$, respectively) [Table 4]. However, ISS, RTS, and ViEWS significantly differed according to the presence of surgery requirements $(p<0.001, p=0.007$, and $p=0.009$, respectively) [Table 5].

The Spearman correlation analysis conducted to determine whether there was a relationship between the trauma scoring systems and hospital stay according to the mortality status revealed a moderate positive correlation between ISS and length of hospital stay in the survivor group, while no such correlation was observed in the mortality group $(r=0.545, \quad p<0.001 \quad$ and $r=-0.125, \quad p=0.841$, respectively). There was a weak negative correlation between RTS and length of hospital stay in the survivor group but no correlation in the mortality group $(r=-0.274, \quad p<0.001, \quad r=0.412, \quad p=0.490$, respectively). Lastly, a weakly positive correlation was detected between ViEWS and length of hospital stay in the survivor group, and a very high level of negative correlation was found in the mortality group $(r=0.304, \quad p<0.001$ and $r=-0.894, \quad p=0.041$, respectively) [Figure 4].

Table 3. Clinical outcomes with the first 24 hours

\begin{tabular}{|l|c|c|c|c|}
\hline \multicolumn{1}{|c|}{ Trauma Scoring } & $\begin{array}{c}\text { Discharge from } \\
\text { hospital }\end{array}$ & Good prognosis & Poor prognosis & p value \\
\hline ISS & $3(1-30)$ & $17(2-54)$ & $41(1-66)$ & $<0.001$ \\
\hline RTS & $7.841(7.108-7.841)$ & $7.84(6.904-7.841)$ & $6.392(1.605-7.841)$ & $<0.001$ \\
\hline ViEWS & $1(1-6)$ & $1(1-7)$ & $9(3-20)$ & $<0.001$ \\
\hline
\end{tabular}

ISS, Injury Severity Score; RTS, Revised Trauma Score; ViEWS, VitalPAC Early Warning Score 
Table 4. Relationship between trauma scores and LHS

\begin{tabular}{|l|c|c|c|}
\hline & LHS $\leq 3$ & LHS $>3$ & p value \\
\hline Length of hospital stay (days) & $2(2-3)$ & $9(4-30)$ & 0.104 \\
\hline ISS & $16.5(3-50)$ & $18(1-66)$ & 0.117 \\
\hline RTS & $7.841(6.90-7.841)$ & $7.841(4.653-7.841)$ & 0.136 \\
\hline ViEWS & $1(1-6)$ & $2(1-10)$ & \\
\hline
\end{tabular}

LHS, length of hospital stay; ISS, Injury Severity Score; RTS, Revised Trauma Score; ViEWS, VitalPAC Early Warning Score

Table 5. Relationship between trauma scores and surgery requirement

\begin{tabular}{|l|c|c|c|}
\hline & Surgery required $\mathbf{( n = 3 9 2 )}$ & Surgery not required (n=36) & p value \\
\hline ISS & $5(1-66)$ & $17.5(3-54)$ & $<0.001$ \\
\hline RTS & $7.841(1.605-7.841)$ & $7.841(6.085-7.841)$ & 0.007 \\
\hline ViEWS & $1(1-20)$ & $1(1-8)$ & 0.009 \\
\hline
\end{tabular}

ISS, Injury Severity Score; RTS, Revised Trauma Score; ViEWS, VitalPAC Early Warning Score

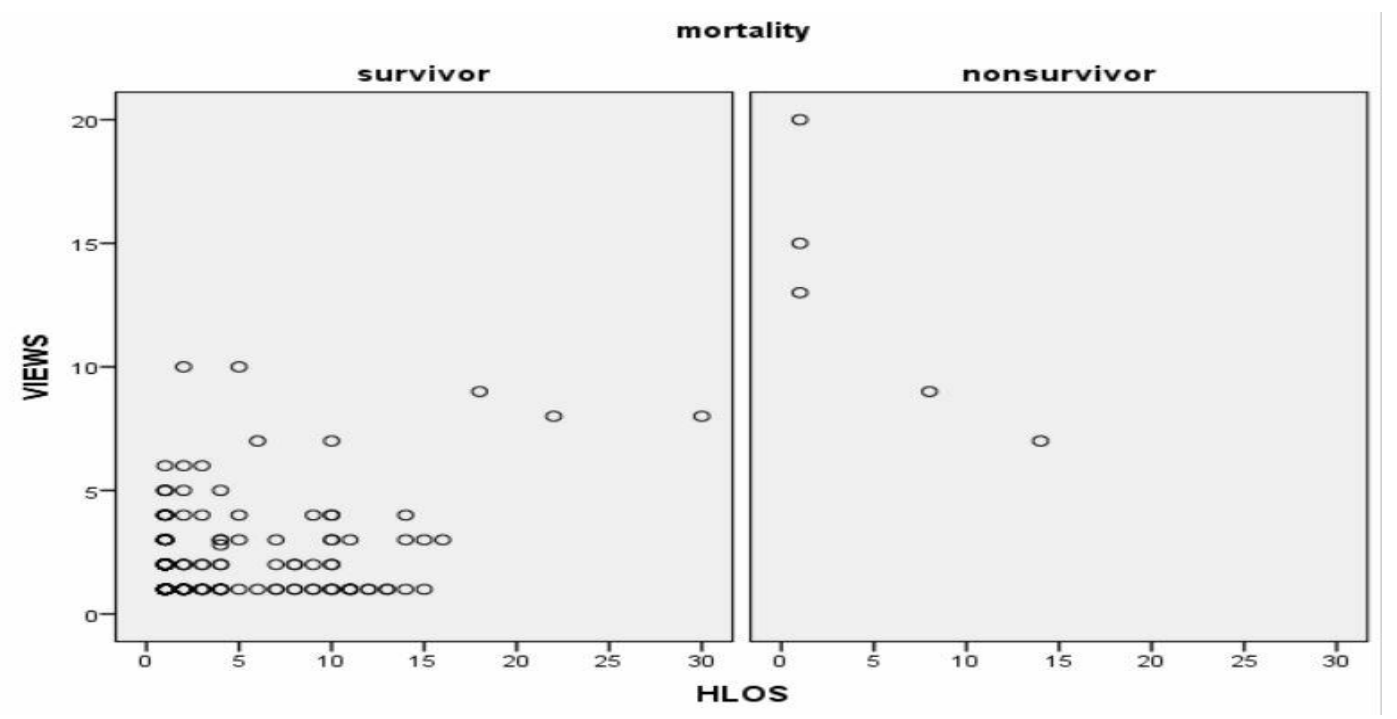

Figure 4.Correlation analysis between VİEWS and mortality

\section{DISCUSSION}

In our study, the ability of ISS, RTS, and ViEWS scoring systems to predict short-term mortality was investigated in multi-trauma patients. To the best of our knowledge, this is the first study in the literature to compare the AUC values of these scoring systems. It was concluded that ISS, RTS, and ViEWS could be used as independent predictors for short-term mortality, and none of these scoring systems had superiority over the others in this respect.

The ability of scoring systems developed for prehospital evaluation to predict mortality and prognosis has been previously discussed in the literature ${ }^{7,8,13-17}$.
In their study with elderly trauma patients, Javali et al. showed a significant relationship of mortality with ISS, RTS, the New Injury Severity Score, and the Trauma Injury Severity Score (TRISS). The authors determined the cut-off values of ISS, NISS, RTS, and TRISS as 15, 17, 7.108, and 91.6, respectively, at which the sensitivity values of TRISS and RTS were higher than the other trauma systems and the specificity values of NISS were higher than the other trauma systems ${ }^{18}$. In a study by Ünlü et al. conducted with ICU patients, RTS and TRISS had a significant relationship with mortality in trauma patients ${ }^{19}$. In a retrospective study of trauma patients over 65 years of age, the relationship between ISS and RTS and 
mortality was statistically significant ${ }^{20}$. In another study evaluating the predictability of RTS and ISS in elderly trauma patients, the cut-off values were $\leq 6$ and $\geq 13.5$, respectively, at which the sensitivity values of RTS were higher than ISS and the specificity values were similar ${ }^{21}$. Çetinkaya et al. prospectively evaluated patients presenting to the emergency department and determined the cut-off, sensitivity, and specificity values of ViEWS as $10.83,78.95 \%$, and $89.73 \%$, respectively (22). In our study, the cutoff value was $>18$ for ISS, $\leq 4.653$ for RTS, and $>6$ for ViEWS (sensitivity: 80\%, 60\%, and 100\%; specificity: $86.98 \%, 100 \%$, and $98.37 \%$, respectively). The AUC values of ISS, RTS, and ViEWS were 84.7, 79.5, and 99.6, respectively, with no statistically significant difference among the scoring systems.

In their 2020 study evaluating geriatric trauma cases, Jiang et al. revealed a relationship between length of hospital stay and mortality. In addition, in this study, ISS, NISS, and TRISS outperformed APACHE II (Acute Physiology and Chronic Health Evaluation II) in terms of in-hospital mortality ${ }^{23}$. Similarly, Adiyaman et al. showed the presence of a relationship between mortality and length of hospital stay. In this study, it was also stated that low RTS increased mortality ${ }^{24}$. In the current study, consistent with the literature, a significant relationship was found between length of hospital stay and mortality. However, we observed no significant relationship between the length of hospital stay and any of the scoring systems evaluated. In the mortality group, length of hospital stay had no correlation with ISS and RTS, but it had a very high level of negative correlation with ViEWS.

In a study in which 200 trauma patients over the age of 60 were examined, $83 \%$ of the patients were discharged after hospital treatment and $17 \%$ died $^{18}$. In ICU studies, the rate of cases that died due to trauma-related causes can reach $20 \%$ or higher ${ }^{19,24,25}$. Since we conducted our study in the emergency department, we expected the mortality rates to be lower and investigated the results of the first 24-hour outcomes and 30-day mortality data.

Priterch et al. emphasized that the first 24 hours was the riskiest period in the mortality evaluation of trauma patients, and they found a significant relationship between the first 24-hour mortality and ViEWS (12). In a study including 106 trauma patients, $5.7 \%$ were referred to the ICU of an external center and $18.9 \%$ died after treatment ${ }^{24}$. In a retrospective study conducted with 502 patients, Jo et al. reported that $36.8 \%$ of the patients were admitted to the ICU while the remaining $63.2 \%$ were admitted to hospital clinics, and a statistically significant relationship was found between ICU and inpatient clinic admission and mortality ${ }^{25}$. In a study examining trauma patients followed up in the ICU, $68.5 \%$ of the patients were admitted to inpatient clinics and $19.4 \%$ died. A statistically significant relationship was found between hospitalization and mortality ${ }^{26}$. In our study, within the first 24 hours of presentation, $19.1 \%$ of the patients were admitted to inpatient clinics, $1.8 \%$ were admitted to the ICU, and three patients $(0.68 \%)$ died. In the examination of 30-day mortality, we determined that one patient $(12.5 \%)$ who had been admitted to the ICU and one $(1.2 \%)$ who had been admitted to a clinic died. No mortality was observed in any of the patients who were discharged from hospital or referred to an external center, and these results were statistically significant. In our evaluation of prognosis and discharge from hospital within the first 24 hours, we found that ISS, RTS, and ViEWS had a statistically significant relationship with prognosis.

In a study conducted with 502 trauma patients, 31.8\% required surgery, but no statistically significant relationship was found between surgery requirement and mortality ${ }^{25}$. Similarly, in another study including 108 trauma patients, $6.5 \%$ of them were admitted to the ICU after an operation, and no statistically significant relationship was found between surgery requirement and mortality ${ }^{26}$. In their retrospective study examining 30-day mortality, Yazar et al. also did not find a significant relationship between surgery requirement and mortality ${ }^{27}$. In the current study, all cases that resulted in mortality were in the nonoperated group, and as a contribution to the literature, we also investigated the relationship of ISS, RTS, and ViEWS with surgery requirement and found that all three scoring systems were statistically significantly correlated with surgery requirement. Our study aimed to compare anatomical and physiological scoring systems. Although it has been determined that each of these systems is effective in determining prognosis, it has also been observed that they do not have superiority over each other. This may also indicate the need for new and improved scoring systems. Early intervention for the patient and the predictability of the prognosis cannot be achieved with only anatomical examination, and physiological parameters alone may be insufficient to determine the prognosis. On the other hand, scoring systems that are easy to apply by physicians should be 
preferred in order to make the most effective triage at the earliest time in emergency departments where patient admission for 24 hours is over 1,000. Our study showed that ISS, RTS, and ViEWS alone are effective in determining prognosis in trauma patients. This is important in terms of expanding the field of preference of the physician in first care.

In our prospective study, the scores were calculated according to the patients' presentation complaints and lesions. During the follow-up, control examinations could not be performed, and possible changes in scores could not be observed due to their early admission to inpatient clinics or the ICU.

In this study, in addition to their relationship with mortality, it should be kept in mind that the investigated scoring systems may also be related to the length of hospital stay and surgery requirement. It was observed that ISS, RTS, and ViEWS had a significant relationship with 30-day mortality. There was also no statistically significant difference in terms of the ISS, RTS, and ViEWS according to the length of hospital stay and surgery requirement. Scoring systems are widely used in emergency departments and ICUs not only for triage purposes but also as prognostic indicators. Comprehensive studies are required to gain knowledge on using existing scoring systems more effectively and developing new scoring systems.

Yazar Katkıları: Çalıșma konsepti/Tasarımı: HȘA, SÖ, AA; Veri toplama: EK; Veri analizi ve yorumlama: HŞA; Yazı taslağı: EK, SEE; İceriğin eleștirel incelenmesi: SEE; Son onay ve sorumluluk: HSA, AA SÖ, EK, SEE; Teknik ve malzeme desteği: SÖ; Süpervizyon: SÖ; Fon sağlama (mevcut ise): yok.

Etik Onay: Bu çalışma için Ümraniye Eğitim ve Araştırma Hastanes Klinik Araştırmalar Etik Kurulundan 22.05.2019 tarih ve 60 sayll kararı ile etik onay alınmıștır.

Hakem Değerlendirmesi: Dış bağımsız.

Çıkar Çatışması: Yazarlar çıkar çatışması beyan etmemişlerdir. Finansal Destek: Yazarlar finansal destek beyan etmemişlerdir.

Author Contributions: Concept/Design : HSA, SÖ, AA; Data acquisition: EK; Data analysis and interpretation: HŞA; Drafting manuscript: EK, SEE; Critical revision of manuscript: SEE; Final approval and accountability: HŞA, AA, SÖ, EK, SEE; Technical or material support: SÖ; Supervision: SÖ; Securing funding (if available) n/a.

Ethical Approval: For this study, ethical approval was obtained from the Ethics Committee of Umraniye Training and Research Hospital for Clinical Research by its decision No. 60 dated 22.05.2019.

Peer-review: Externally peer-reviewed.

Conflict of Interest: Authors declared no conflict of interest.

Financial Disclosure: Authors declared no financial support

\section{REFERENCES}

1. Hietbrink F, Koenderman L, Rijkers GT, Leenen LPH. Trauma: the role of the innate immune system. World J Emerg Surg. 2006;20:15.
2. Keel M, Trentz O. Pathophysiology of polytrauma. Injury. 2005;36:691-709.

3. Mariani A, Casella G, Aseni P. From trauma scoring system to early appropriate care. operative techniques and recent advances in acute care and emergency surgery. In Operative Techniques and Recent Advances in Acute Care and Emergency Surgery (pp.129-140). New York, Springer, 2019.

4. Gofrit ON, Leibovici D, Shapiro SC, Shemer J, Stein M, Michaelson M. The trimodal death distribution of trauma victims: military experience from the LebanonWar. Mil Med. 1997;162:24-6.

5. Bouzat P, Broux C, Ageron FX, Thony F, Arvieux C, Tonetti $\mathrm{J}$ et al. Trauma network for severely injured patients. Ann Fr Anesth Reanim. 2013;32:531-4.

6. Joosse P, Soedarmo S, Luitse JS, Ponsen KJ. Trauma outcome analysis of a Jakarta University Hospital using the TRISS method: validation and limitation in comparison with the major trauma outcome study. Trauma and Injury Severity Score. J Trauma. 2001;51:134-40.

7. Baker SP, O'Neill B, Haddon W Jr, Long WB. The injury severity score: a method for describing patients with multiple injuries and evaluating emergency care. J Trauma. 1974;14:187-96.

8. Champion HR, Sacco WJ, Copes WS, Gann DS, Gennarelli TA, Flanagan ME. A revision of the trauma score. J Trauma. 1989;29:623-9.

9. Shi j, Shen J, Zhu M, Wheeler KK, Lu B, Kenney B et al. A new weighted injury severity scoring system: beter predictive power for adult trauma mortality. Injury Epidemiology. 2019;6:40.

10. Haider AA, Azim A, Rhee PM, Kulvatunyou N, Ibraheem K, Tang A et al. Substituting systolic blood pressure with shock index in the National Trauma Triage Protocol. J Trauma Acute Care Surg. 2016;81:1136-41.

11. Subbe CP, Kruger M, Rutherford P, Gemmel L. Validation of a modified early warning score in medical admissions. QJMed. 2001;94:521-6.

12. Prytherch DR, Smith GB, Schmidt PE, Featherstone PI. ViEWS - Towards a national early warning score for detecting adult inpatient deterioration. Resuscitation. 2010;81:932-7.

13. Galvagno SM, Massey M, Bouzat P, Vesselinov R, Levy MJ, Millin MG et al. Correlation between the revised trauma score and injury severity score: implications for prehospital trauma triage. Prehosp Emerg Care. 2019;23:263-70.

14. Husum H, Strada G. Injury severity score versus new injury severity score for penetrating injuries. Prehosp Disast Med. 2002;17:27-32.

15. Stevenson M, Segui0-Gomez M, Lescohler I, Di Scala C, McDonald-Smith G. An overview of the injury severity score and the new injury severity score. Inj Prev. 2001;7:10-3.

16. Norouzi V, Feizi I, Vatankhah S, Pourshaikhian M. Calculation of the probability of survival for trauma 
patients based on trauma score and the injury severity score model in Fatemi hospital in Ardabil. Arch Trauma Res. 2013;2:30-5.

17. Bouzat P, Legrand R, Gillois P, Ageron FX, Brun J, Savary D et al. TRENAU Group. Prediction of intrahospital mortality after severe trauma: which prehospital score is the most accurate? Injury Int $\mathrm{J}$ Care Injured. 2016;47:14-8.

18. Javali RH, Krishnamoorthy, Patil A, Srinivasarangan M, Suraj, Sriharsha. Comparison of injury severity score, new injury severity score, revised trauma score and trauma and injury severity score for mortality prediction in elderly trauma patients. Indian J Crit Care Med. 2019;23:73-7.

19. Ünlü AR, Ülger F, Dilek A, Barış $S$, Murat N, Sarihasan B. Evaluation of the relationship between revised trauma score, and trauma and injury severity scores with prognosis of trauma patients in intensive care unit. J Turk Anaesth Int Care. 2012;40:128-35.

20. Aydın ŞA, Bulut M, Fedakar R, Özgürer A, Özdemir F. Trauma in the elderly patients in Bursa. Turkish Journal of Trauma and Emergency Surgery. 2006;12:230-4.

21. Yousefzadeh-Chabok S, Hosseinpour M, Kouchakinejad-Eramsadati L, Ranjbar F, Malekpouri $\mathrm{R}$, Razzaghi A et al. Comparison of revised trauma score, injury severity score and trauma and injury severity score for mortality prediction in elderly trauma patients, Turkish Journal of Trauma and Emergency Surgery. 2016;22:536-40.

22. Çetinkaya HB, Köksal Ö, Sigirli D, Leylek EH, Karasu $\tilde{O}$. The predictive value of the modified early warning score with rapid lactate level (ViEWS-L) for mortality in patients of age 65 or older visiting the emergency department. Intern Emerg Med. 2017;12:1253-7.

23. Jiang $\mathrm{L}$, Zheng $\mathrm{Z}$, Z Zhang $\mathrm{M}$. The incidence of geriatric trauma is increasing and comparison of different scoring tools for the prediction of in-hospital mortality in geriatric trauma patients. World J Emerg Surg. 2020;15:59.

24. Adiyaman E, Tokur ME, Bal ZM, Gökmen AN, Koca U. Retrospective analysis of trauma patients who were treated and followed in anesthesia intensive care unit. Turk J Intensive Care. 2019;17:146-53.

25. Jo S, Lee JB, Jin YH, Jeong T, Yoon J, Choi SJ et al. Comparison of the trauma and injury severity score and modified early warning score with rapid lactate level (the ViEWS-L score) in blunt trauma patients. Eur J Emerg Med. 2014;21:199-205.

26. Kara I, Altınsoy S, Gök U, Onur A, Sarıbabıççı R. Mortality analysis of trauma patients in general intensive care unit of a state hospital. Turk J Intense Care. 2015;13:68-74.

27. Yazar MA, Sarıkuş Z, Horasanlı E. Thirty-day mortality outcomes of trauma patients in the intensive care unit: a three-year retrospective study. Turk J Intensive Care. 2019;17:18-24. 